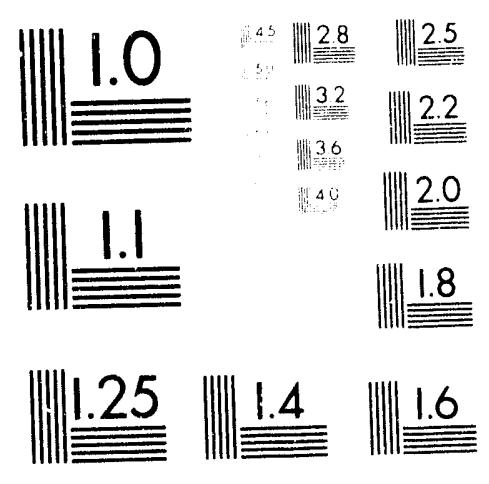



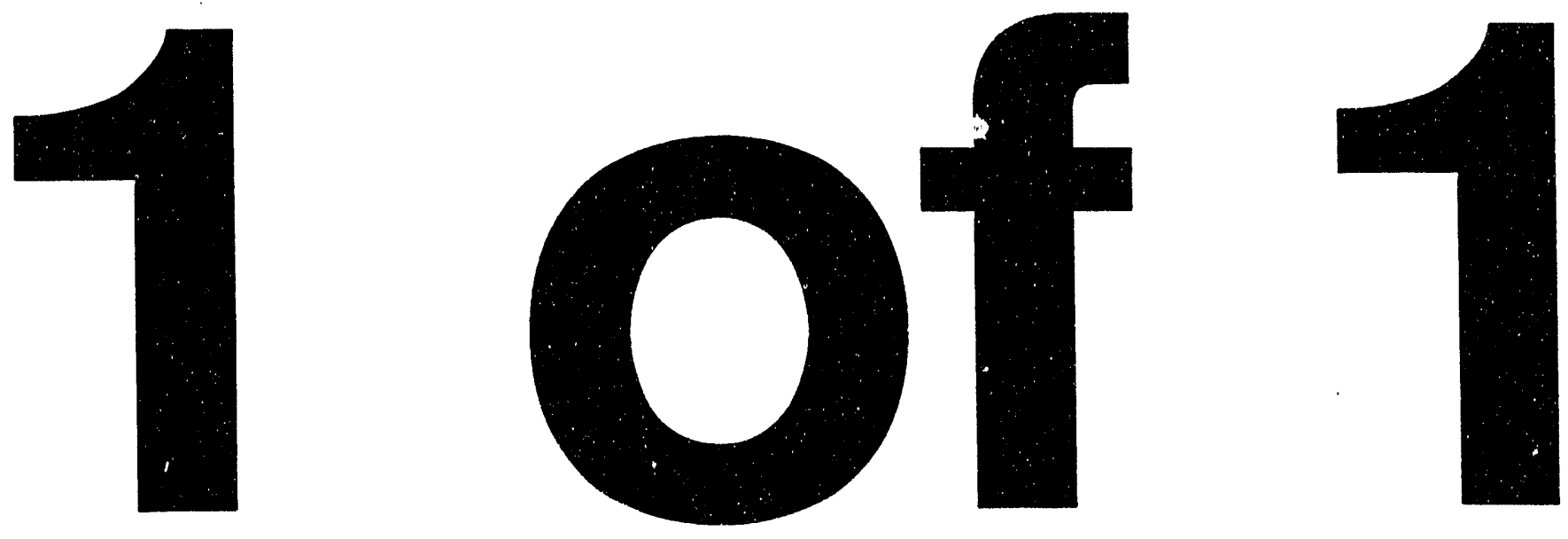


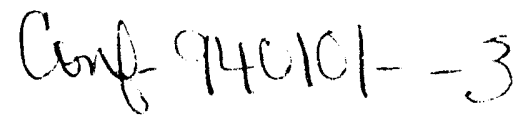

LA-UR- 93-3060
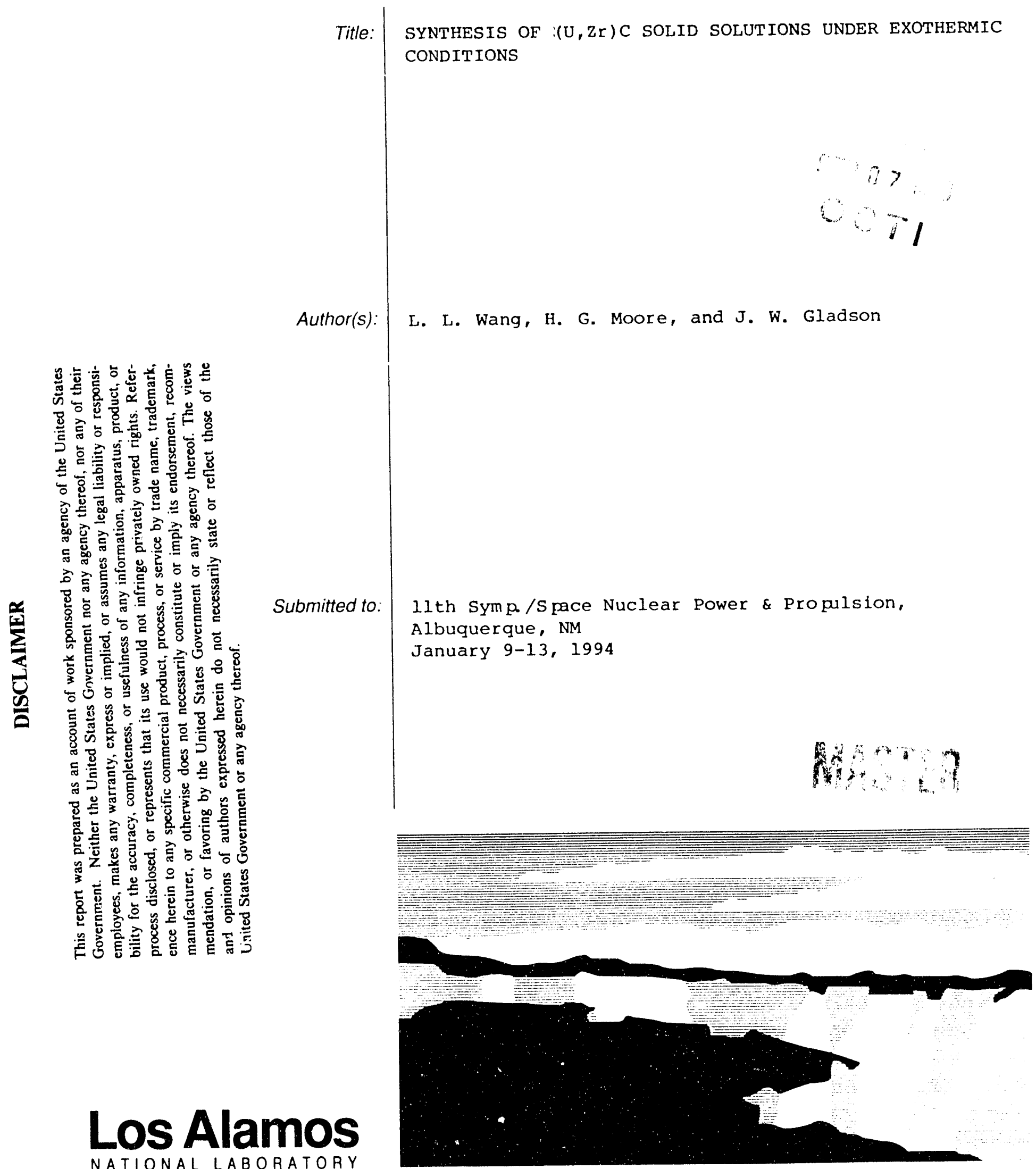

1lth Symp./Space Nuclear Power \& Propulsion, Albuquerque, NM

January 9-13, 1994

\section{Los Alamos NATIONAL LABORATORY}

Los Alamos Nationai Laboratory, an affirmative action/equal opportunity employer, is operated by the University of Californı for the U.S. Department of EnerGy under contract W-7405-ENG-36. By acceptance of this article, the publisher recognizes that the U.S. Government retains a nonexclusive, royalty-free license ic publish or reproduce the published form of this contribution, or to allow others to do so, for U.S. Government purposes. The Los Alamgs National Laboratory requests that the publisher identify this article as work pertormed under the auspices of the U.S. Department of Energy. 


\section{SYNTHESIS OF (U,Zr)C SOLID SOLUTIONS UNDER EXOTHERMIC CONDITIONS}

Lily L. Wang, H. Gene Moore, and Jane W. Gladson

Mail Stop E505

NMT-1 Group

Nuclear Material Technology Division

Los Alamos National Laboratory, NM 87545

(505) 665-8020

Eleventh Symposium on Space Nuclear Power and Propulsion

Albuquerque, New Mexico

9-13 January 1994

Version Number: 1

August 20, 1993 


\title{
SYNTHESIS OF (U,Zr)C SOLID SOLUTIONS UNDER EXOTHERM'C CONDITIONS
}

\author{
Lily L. Wang, H. Gene Moore, and Jane W. Gladson \\ Mail Stop E505 \\ NMT-1 Group \\ Nuclear Material Technology Division \\ Los Alamos National Laboratory, NM 87545
}

(505) 665-8020

\begin{abstract}
The reactions of forming $(\mathrm{U}, \mathrm{Zr}) \mathrm{C}$ solid solutions from their elemental components or similarly less stable reactants such as $\mathrm{UC}_{2}$ are strongly exothermic due to the high stability of these solid solutions. A simple approach of utilizing this heat of formation energy to assist the solid solution reaction process is to intimately mix the less stable reactant powders and then pressed them into a compact. The compact is then heated to the ignition temperature of the reaction. The feasibility of this reaction method to synthesize (U,Zr)C solid solutions has been demonstrated in this study. The preliminary results also show that both the initial composition and the heating rate have a significant effect on the nature of the reaction process. As expected the degree of powder mixing was also found to affect the completeness of the reaction.
\end{abstract}

\section{INTRODUCTION}

Proposed manned missions to Mars require nuclear propulsion reactors with high specific impulse in order to reduce the travel time. Mixed uranium-refractory metal carbides such as ( $\mathrm{U}, \mathrm{Zr}) \mathrm{C}$ solid solutions are very promising as the fuel for this space application because of their high melting points (up to $3000{ }^{\circ} \mathrm{C}$ ) and corrosion resistance properties [Butt and Wallace]. Past methods used to synthesize these solid solutions have involved heating mixture compacts of the reactant powders to an elevated temperature and holding at this elevated temperature for an extended period of time. This hold period appears unnecessary considering the high enthalpy of formation of these solid solutions. If the starting powders consist of elemental components or less stable reactant such as UC or UC2, the reaction is exothermic enough as illustrated later that it can self propagate, resulting in a combustion type of reaction. The heats of formation in the $\mathrm{U}-\mathrm{Zr}-\mathrm{C}$ system makes it an excellent candidate for the combustion synthesis process which has received much attention as an excellent method for synthesizing refractory materials. The advantages of the combustion synthesis method are discussed in several review papers [Munir 1988, Munir and Tamburini 1989, Subrahamany and Vijayakumar 1992]. In this preliminary study we investigated a variation of combustion synthesis process to synthesize the $(\mathrm{U}, \mathrm{Zr}) \mathrm{C}$ solid solutions. In this method compacts consisting of mixtures of $\mathrm{U}, \mathrm{Zr}$, and $\mathrm{C}$ powders or mixtures of $\mathrm{U}, \mathrm{Zr}, \mathrm{UC}_{2}$, and $\mathrm{C}$ powers are heated in a furnace to a temperature at which the exothermic reaction is initiated and completed in a short time. The objective of this study is to determine the feasibility of forming these $(\mathrm{U}, \mathrm{Zr}) \mathrm{C}$ solid solutions using this exothermic process. This investigation also examines the effects of starting powder compositions and the rate of heating.

\section{ADIABATIC COMBUSTION TEMPERATURE}

In a powder compact, when the reaction between the reactant particles is sufficiently exothermic and the heat generated is retained to heat the next layer of the reactants, the reaction can self propagate in a form of combustion wave until the reactants are consumed. This propensity to self propagate can be assessed from the value of the adiabatic combustion temperature of the reaction. The adiabatic combustion temperature is the highest temperature the reaction system can achieve without any heat loss to the environment and can be calculated from tabulated th.ermodynamic data.

Three reactions of interest to this study are

$$
\begin{aligned}
& x U+(1-x) Z r+C \rightarrow U_{x} Z r(1-x) C \\
& x / 2 U C_{2}+x / 2 U+(1-x) Z r+C \rightarrow U_{x} Z r(1-x) C \\
& x U C+(1-x) Z r+C \rightarrow U_{x} Z_{(1-x) C}
\end{aligned}
$$


where $\mathrm{x}$ varies from 0 to 1 . The adiabatic combustion temperature $\left(\mathrm{T}_{\mathrm{ad}}\right)$ can be calculated from

$$
\Delta H_{298}^{0}=\int_{298}^{T_{a d}} C_{p} d t
$$

where $\Delta \mathrm{H}_{298}^{\mathrm{O}}$ is the enthalpy of the reaction for forming $\mathrm{U}_{\mathrm{x}} \mathrm{Zr}(1-\mathrm{x}) \mathrm{C}$ at $298 \mathrm{~K}$, and $\mathrm{C}_{\mathrm{p}}$ is the heat capacity of the products. The enthalpies of reaction for the three above reactions are different due to different starting reactants and are calculated by subtracting the sum of the enthalpies of formation of the reactants from the enthalpy of formation of the product. To circumvent the lack of published data, the heat capacities are estimated by applying the Ncumann-Kopp rule and the enthalpies of formation of the various $U_{x} \mathrm{Zr}_{(1-\mathrm{x})} \mathrm{C}$ compositions by assuming that $\mathrm{ZrC}$ and UC form ideal solution using the basic thermodynamic data shown ii Table 1.

TABLE 1. Thermodynamic Data*

\begin{tabular}{|c|c|c|c|c|c|c|}
\hline \multirow[b]{2}{*}{ Phase } & \multicolumn{5}{|c|}{$\mathrm{Cp}(\mathrm{J} / \mathrm{molc})=\mathrm{a}+\mathrm{bT}+\mathrm{cT}^{2}+\mathrm{dT}^{2}+\mathrm{eT}^{3}$} & \multirow[b]{2}{*}{$\begin{array}{l}\Delta \mathrm{H}_{\mathrm{f}-298}^{\mathrm{O}} \\
(\mathrm{KJ} / \mathrm{mole})\end{array}$} \\
\hline & $a$ & $b \times 10^{3}$ & $c \times 10^{-5}$ & $\mathrm{~d} \times 10^{6}$ & $\mathrm{e} \times 10^{8}$ & \\
\hline $\mathrm{ZrC}$ & 51.13 & 3.39 & -12.97 & -- & $-\cdot$ & 207.1 \\
\hline UC & 50.96 & 25.72 & 6.19 & -18.68 & 57.17 & 97.5 \\
\hline $\mathrm{UC}_{2}$ & - & -- & -. & -. & -- & 88.3 \\
\hline
\end{tabular}

* Data from [Kubaschewski et al 1993]except Cp of UC from [Holley 1984].

The detailed steps of calculating $\mathrm{T}_{\mathrm{ad}}$ is elucidated elsewhere [Munir 1988], and it has been empirically determined that for a solid-solid reaction system to be sclfsustaining, $\mathrm{T}_{\mathrm{ad}}$ needs be $>1600^{\circ} \mathrm{C}$. The calculated resuits, assuming the final product is solid at $\mathrm{T}_{\mathrm{ad}}$, are

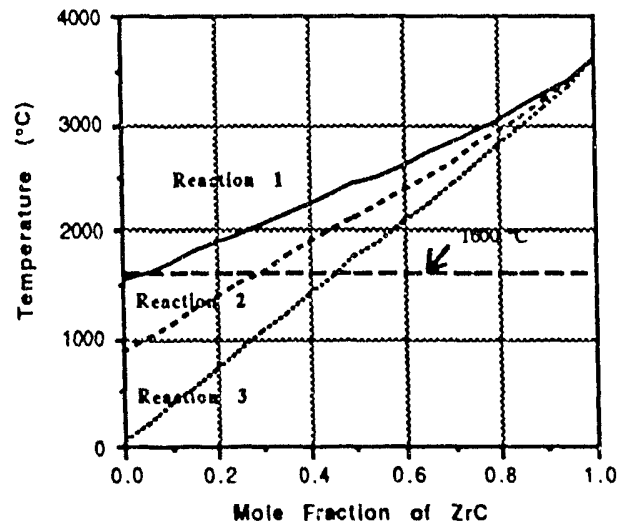
shown in Figure 1. In gen ral $T_{\text {ad }}$ increases as the composition moves toward the $\mathrm{ZrC}$ rich side. It can be seen in Table 1 that the formation reaction of $\mathrm{ZrC}$ is significantly more exothermic than that of $\mathrm{UC}$, sec Table 1 , and therefore the energy release from the bond formation between $\mathrm{Zr}$ and $\mathrm{C}$ is the major heat source for raising the reaction temperature. It can bs seen in Figure 1 that nearly all compositions of Reaction 1 can potentially self propagate, while in the case of Reaction 2 that condition is true for composition with the $\mathrm{ZrC}$ mole fraction greater than 0.3 and in the case of Reaction 3 for ZrC mole fraction greater than 0.45 . The more exothermic Reactions 1 and 2 were investigated in this study.

\section{$\mathrm{F}$}

IGURE 1. Calculated adiabatic combustion temperature as a function of $\mathrm{ZrC}$ mole fraction

\section{EXPERIMENTAL METHOD}

The reactants used in this study were depleted uranium powder ( -325 mesh), zirconiun powder $(-325$ mesh), graphite powder ( -325 mesh), and $U_{2}$ powder ( -325 mesh). All the sample preparation and reaction experiments were done in glove boxes under argon atmosphere. The powder mixtures were prepared by weighing out appropriate amounts of the powders according to the stoichiometry of the final product to be synthesized, Table 2 , 
and then ball milled for 16 hours. The last mixture was prepared by hand blending for about 10 minutes the appropriate amounts of Mixtures M2 and M4 to make up the desired composition. With the exception of the Mixture M4 $(\mathrm{Zr}+\mathrm{C})$, all other mixtures required $0.5 \mathrm{wt} \%$ of binder (equal weight parts of poly glycol and steric acid) added in order to form an intact compacts. These cylindrical compacts had a diameter of $1.42 \mathrm{~cm}$, a height ranging from 1.19 to $1.59 \mathrm{~cm}$ and a bulk density ranging from about 55 to $70 \%$ of the theoretical density. A $1 / 8^{\prime \prime}(0.318 \mathrm{~cm})$ hole was drilled axially from the center of one end of the compact to about half the height of the sample to allow for placement of a thermocouple.

TABLE 2. Mixtures and Heating Rates Studied

\begin{tabular}{|c|c|c|c|c|c|c|c|c|c|c|}
\hline \multirow[b]{2}{*}{$\begin{array}{l}\text { Mixture } \\
\text { ID }\end{array}$} & \multicolumn{4}{|c|}{$\begin{array}{l}\text { Starting Composition } \\
\text { (wt\%) }\end{array}$} & \multicolumn{3}{|c|}{$\begin{array}{l}\text { Nominal Formula }\left(\mathrm{U}_{\mathrm{x}} \mathrm{Zr}_{1}-\right. \\
\left.\mathrm{x}_{\mathrm{z}}\right)\end{array}$} & \multirow[b]{2}{*}{$\begin{array}{l}\text { Heating Rate } \\
\left({ }^{\circ} \mathrm{C} / \mathrm{min}\right)\end{array}$} & \multirow{2}{*}{\multicolumn{2}{|c|}{$\begin{array}{l}\text { Expected Product } \\
\text { Phases }\end{array}$}} \\
\hline & $\mathrm{UC}_{1.92}$ & $\mathrm{U}$ & $\mathrm{Zr}$ & $\mathrm{C}$ & $x$ & $1-x$ & $\mathrm{z}$ & & & \\
\hline$M 1$ & 37.1 & 33.7 & 25.8 & 3.4 & 0.50 & 0.50 & 1.00 & 30 & $\begin{array}{l}\text { single } \\
\text { solution }\end{array}$ & solid \\
\hline M2 & 0.0 & 67.8 & 26.0 & 6.2 & 0.50 & 0.50 & 0.91 & 30,100 & $\begin{array}{l}\text { single } \\
\text { solution }\end{array}$ & solid \\
\hline M3 & 23.9 & 0.0 & 66.3 & 9.8 & 0.11 & 0.89 & 1.22 & 30 & $\begin{array}{l}\text { solid solu } \\
\text { C }\end{array}$ & tion and \\
\hline M5 & 0.0 & 36.0 & 55.2 & 8.8 & 0.20 & 0.80 & 0.96 & 100 & $\begin{array}{l}\text { single } \\
\text { solution }\end{array}$ & solid \\
\hline M4 & 0.0 & 0.0 & 88.4 & 11.6 & 0.00 & 1.00 & 1.00 & 30,100 & $\mathrm{ZrC}$ & \\
\hline
\end{tabular}

The compacts were neated in a resistance heating furnace under a vacuum of $<10^{-4}$ torr. One of the two thermocouples (W-5\%Re/W-26\%Re type, 1/8" molybdenum sheath diameter) inside of the furnace was inserted into the sample to measure the sample temperature; while the other thermocouple outside of the sample was used for the furnace temperature control. All samples were heated at $30^{\circ} \mathrm{C} / \mathrm{min}$. to $500^{\circ} \mathrm{C}$ and held for 10 to 30 minutes to outgas or burn off the binder. After this outgas stage, the sample was heated up at a rate indicated in Table 2 to 2000 ${ }^{\circ} \mathrm{C}$, above the melting point of $\mathrm{Zr}\left(1852^{\circ} \mathrm{C}\right)$. The temperatures were recorded on a chart recorder. The reacted samples were analyzed by $\mathrm{x}$-ray diffraction and examined in both optical and scanning electron microscopes.

\section{RESULTS}

Only the M4 samples heated at 30 and $100^{\circ} \mathrm{C} / \mathrm{min}$ and the M2 sample heated at $100^{\circ} \mathrm{C} / \mathrm{min}$ showed noticeable exothermic effects, Figure 2, while all the other samples show no noticeable temperature deviation from that of the furnace. In both the M4 samples heated at 30 and $100^{\circ} \mathrm{C} / \mathrm{min}$, the exothermic effect was observed to initiate at about $1760^{\circ} \mathrm{C}$ which is about $100^{\circ} \mathrm{C}$ lower than the melting point of $\mathrm{Zr}\left(1852^{\circ} \mathrm{C}\right)$. The temperature rise was
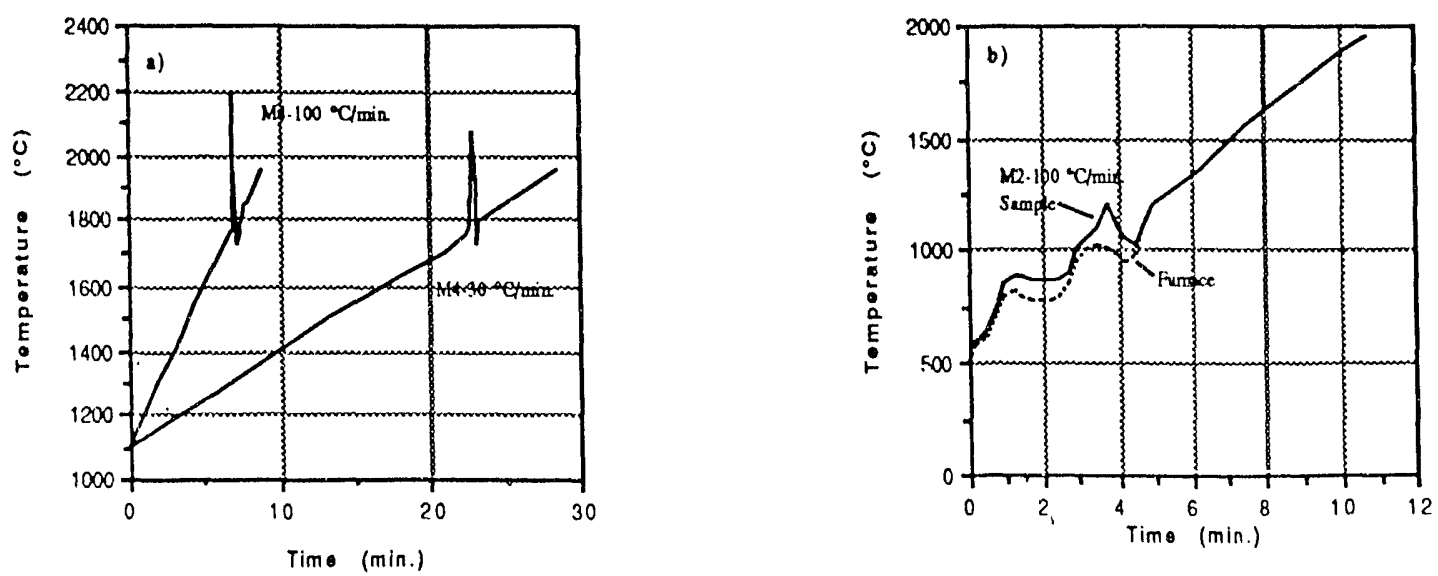

FIGURE 2. Measured sample temperature with time: a) the M4 samples and b) the M2 sample. 
significantly higher in the $100^{\circ} \mathrm{C} / \mathrm{min}$ run than in the $30^{\circ} \mathrm{C} / \mathrm{min}$ run. For the $100^{\circ} \mathrm{C} / \mathrm{min}$ run the maximum temperature reached above $2200^{\circ} \mathrm{C}$, the maximum temperature that could be recorded by the chart recorder, while for the $30^{\circ} \mathrm{C} / \mathrm{min}$ run the maximum temperature measured was $2050^{\circ} \mathrm{C}$. A sample temperature which drops below the general linear rise after the occurrence of the exothermic peak is an effect resulting from the furnace temperature control. Since the control thermocouple also picked up some heat from the reaction, this caused a momentary decrease in power input to the furnace, resulting momentary cooling of the furnace. The exothermic effect in the case of the $\mathrm{M} 2$ sarnple heated at $100{ }^{\circ} \mathrm{C} / \mathrm{min}$ is less conspicuous ( sce Figure $2 \mathrm{~b}$ ) but occurred at about $1050^{\circ} \mathrm{C}$, which is about $80^{\circ} \mathrm{C}$ lower than the melting point of uranium $\left(1132^{\circ} \mathrm{C}\right)$. A temperature rise of about $125^{\circ} \mathrm{C}$ was observed. The oscillation observed in the temperatures traces of this case is an effect of furnace control which had not been optimally tuned in this temperature range. Other than pressure increase due to binder burn off in the low temperature range $\left(\leq 500^{\circ} \mathrm{C}\right)$, no noticeable change in furnace pressure was observed during the experimental runs.

In general the reacted samples appeared lighter in color from the original dark gray to medium gray, and had some increase in volurne. The cylindrical shape was generally retained. Some laminations and cracks were observed in some sampies, but not in the M4 samples which had no binder addition. The reacted M4 samples were also most sintered, while the reacted M3 sample which contained the greatest amount of carbon was most friable.

The $\mathrm{x}$-ray diffraction patterns of six reacted samples along with that of the starting $\mathrm{UC}_{2}$ powder are presented in Figure 3. These patterns exhibit definite solid solution formation in most cases. The M2 samples (30 and 100 ${ }^{\circ} \mathrm{C} / \mathrm{min}$ runs) show to have formed a single solid solution phase, while that of the M1 sample has formed two solid solutions, the M3 sample also has two basic solid solution phases, and the MS sample contains the two basic binary carbides ( $\mathrm{ZrC}$ and UC) and minor amounts of variable composition solid solutions. The M4 sample as expected formed only $\mathrm{ZrC}$ phase. There were two unidentified peaks (at about 21 and $24^{\circ}$ two theta) which are present in all cases and even in the starting $\mathrm{UC}_{2}$ powder. They were later found to be from the Mylar film used to cover the $x$-ray powder samples. In the M3 sample, there are minor amounts of $\mathrm{UC}_{2}$ and $\mathrm{C}$. The lattice parameters of the main solid solutions in the reacted samples are presented in Table 3. Assuming ideal solution so that the lattice parameters follow the Vegard rule, the mole fractions of $\mathrm{ZrC} .96$ in the solid solutions are calculated for each case and presented Table 3.
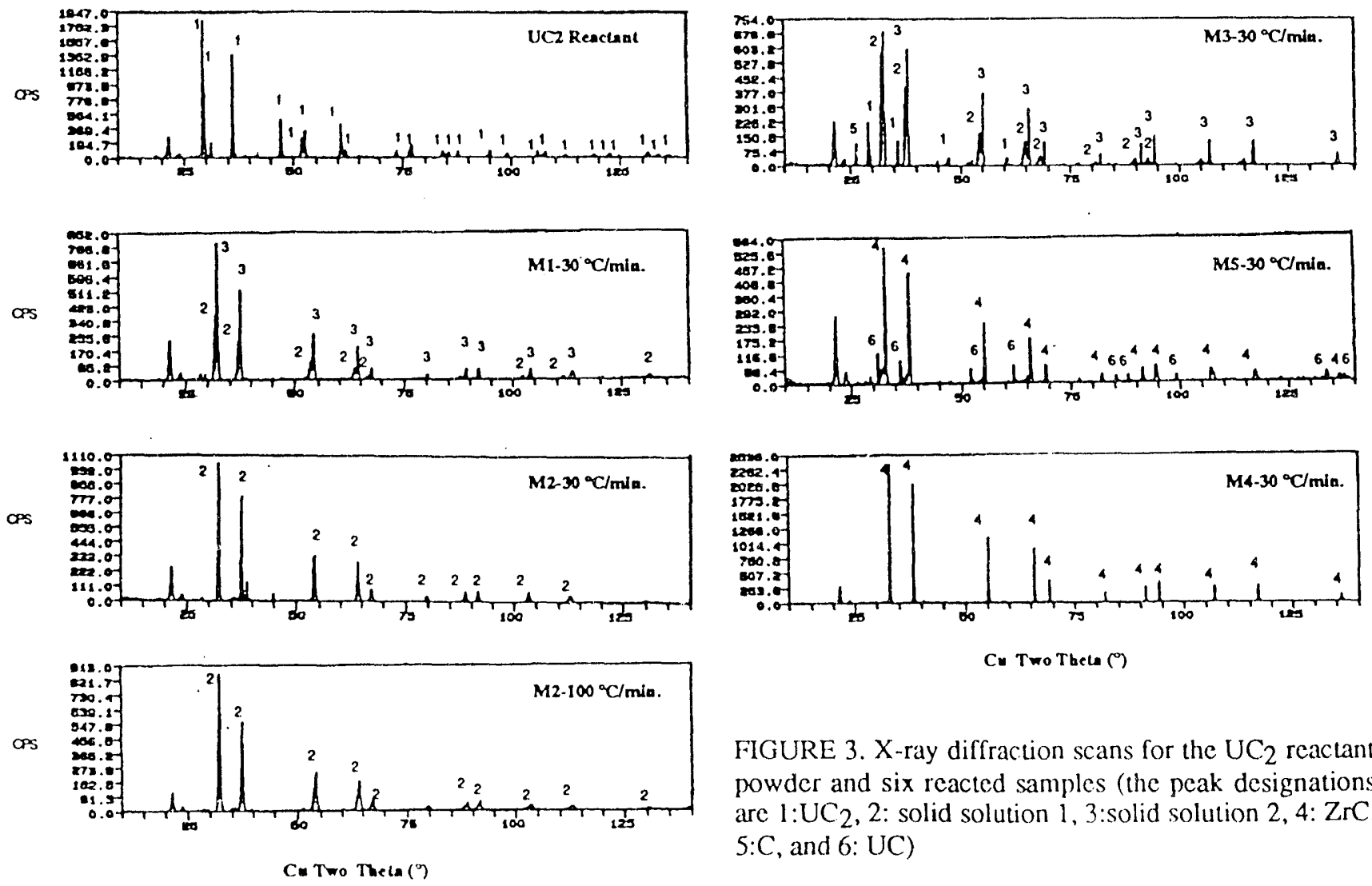

FIGURE 3. X-ray diffraction scans for the $\mathrm{UC}_{2}$ reactant powder and six reacted samples (the peak designations are $1: \mathrm{UC}_{2}, 2$ : solid solution 1,3 :solid solution $2,4: \mathrm{ZrC}$, $5: C$, and $6: U C$ ) 
Table 3: The Lattice Parameters of the Product Solid Solutions*

\begin{tabular}{|c|c|c|c|c|}
\hline \multirow[b]{2}{*}{ Sample } & \multicolumn{2}{|c|}{ Lattice Paramcter $(\AA)$} & \multirow{2}{*}{$\begin{array}{c}\text { Calculatec } \\
\text { fraction } \\
\text { Solid } \\
\text { Solution } 1 \\
\end{array}$} & \multirow{2}{*}{$\begin{array}{c}\text { ZrC.96 } \\
\text { Solid } \\
\text { Solution } 2 \\
\end{array}$} \\
\hline & $a_{1}$ & $a_{2}$ & & \\
\hline $\mathrm{Ml}-30^{\circ} \mathrm{C} / \mathrm{min}$. & 4.847 & 4.793 & 0.43 & 0.64 \\
\hline $\mathrm{M} 2-30^{\circ} \mathrm{C} / \mathrm{min}$ & 4.806 & & 0.59 & \\
\hline $\mathrm{M} 2-100^{\circ} \mathrm{C} / \mathrm{min}$. & 4.804 & & 0.60 & \\
\hline $\mathrm{M} 3-30^{\circ} \mathrm{C} / \mathrm{min}$. & 4.782 & 4.720 & 0.68 & 0.92 \\
\hline $\mathrm{M} 5-30^{\circ} \mathrm{C} / \mathrm{min}$ & 4.961 & 4.696 & 0.00 & 1.00 \\
\hline $\mathrm{M} 4-30^{\circ} \mathrm{C} / \mathrm{min}$ & 4.697 & & 1.00 & \\
\hline
\end{tabular}

Microstructural examination was performed on the longitudinal cross sections of the reacted samples. Since it was difficult to prepare representative surfaces of the reacted M1 and M3 samples due to particle fall out, only the M2, M4 $\left(30^{\circ} \mathrm{C} / \mathrm{min}\right.$.) and M5 samples were examined in detail. As seen in the optical micrograph in Figure 4, the reacted M4 sample exhibits a rather porous yet connected microstructure. Generally a single ZrC phase was found in the sample except in the region around the thermocouple hole where two phases were found. The second phase, shown as the light color phase in Figure 4, contains Mo but no $\mathrm{Zr}$ as revealed by the $\mathrm{X}$-ray energy dispersive spectrum (XEDS) analysis performed in a SEM. This finding indicates that the sample interacted with the Mo sheath of the thermocouple. From the appearance of the microstructure, the Mo phase appeared to have melted and subsequently intermixed with the $\mathrm{Zr}-\mathrm{C}$ mixture. Since the melting point of Mo is $2610^{\circ} \mathrm{C}$, the actual reaction temperature was probably much higher than the measured maximum reaction temperature $\left(2050^{\circ} \mathrm{C}\right)$. Although carbon could not be detected with the XEDS, it is likely the Mo containing phase is a carbide phase. The M2 sample was also found to have a major phase identified by the XEDS analysis to contain both uranium and zirconium. This phase corrisponds to the solid solution found in the $x$-ray diffracion analysis. The M2 sample also contains a minor secondary ,hase which has uranium but no zirconium, Figure 5. This secondary phase was most evident in the region near the exterior surfaces and around the thermocouple holes where heat loss is expected to be greater. The amount of this uranium-containing phase (either a uranium carbide or pure uranium) was below the detection limit of the $x$-ray diffraction analysis. In the case of the M5 sample, the microstructure is rather heterogeneous, Figure 6 , and at least three phases were observed: a zirconium containing phase, a phase containing variable amounts of uranium and zirconium, and a uranium containing phase. These three phases correspond to $\mathrm{ZrC}$, variable (U, $\mathrm{Zr}) \mathrm{C}$ solid solution, and UC as identified by $\mathrm{x}$-ray diffraction, Figure 3.

FIGURE 4. Optical micrograph of the M4-30 ${ }^{\circ} \mathrm{C} / \mathrm{min}$. sampie (1: molybdenum containing phase, $2: \mathrm{Zr}$ ', phase.

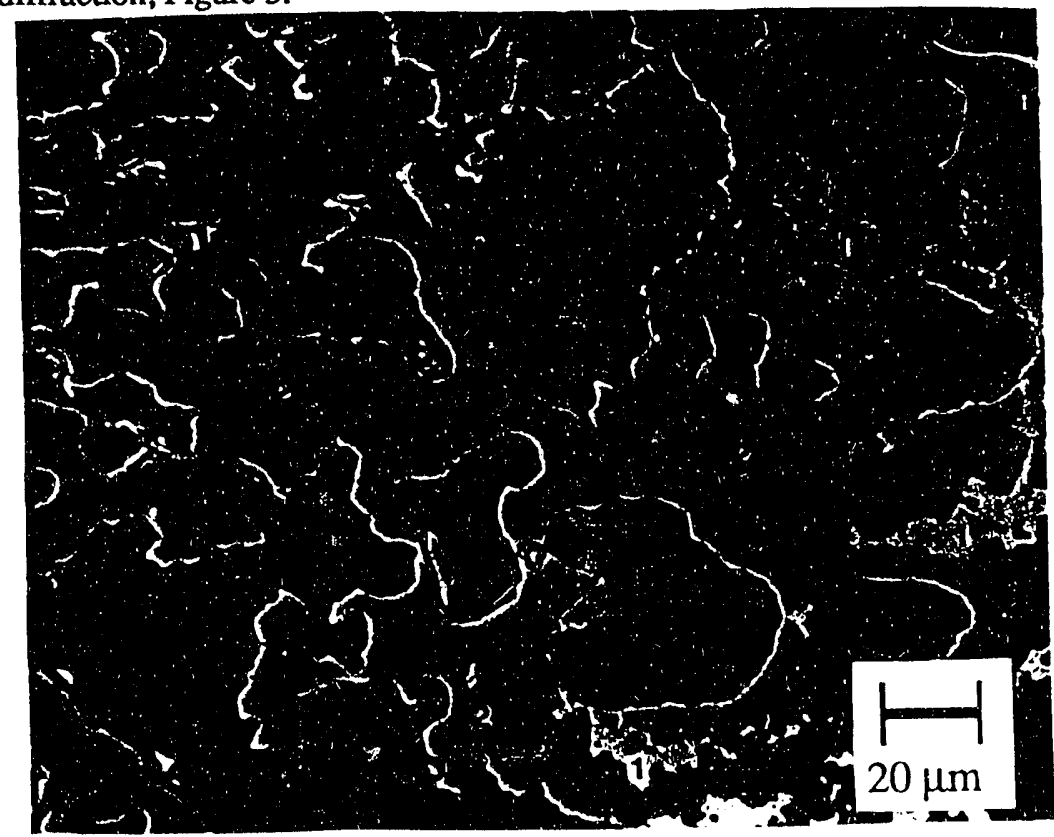




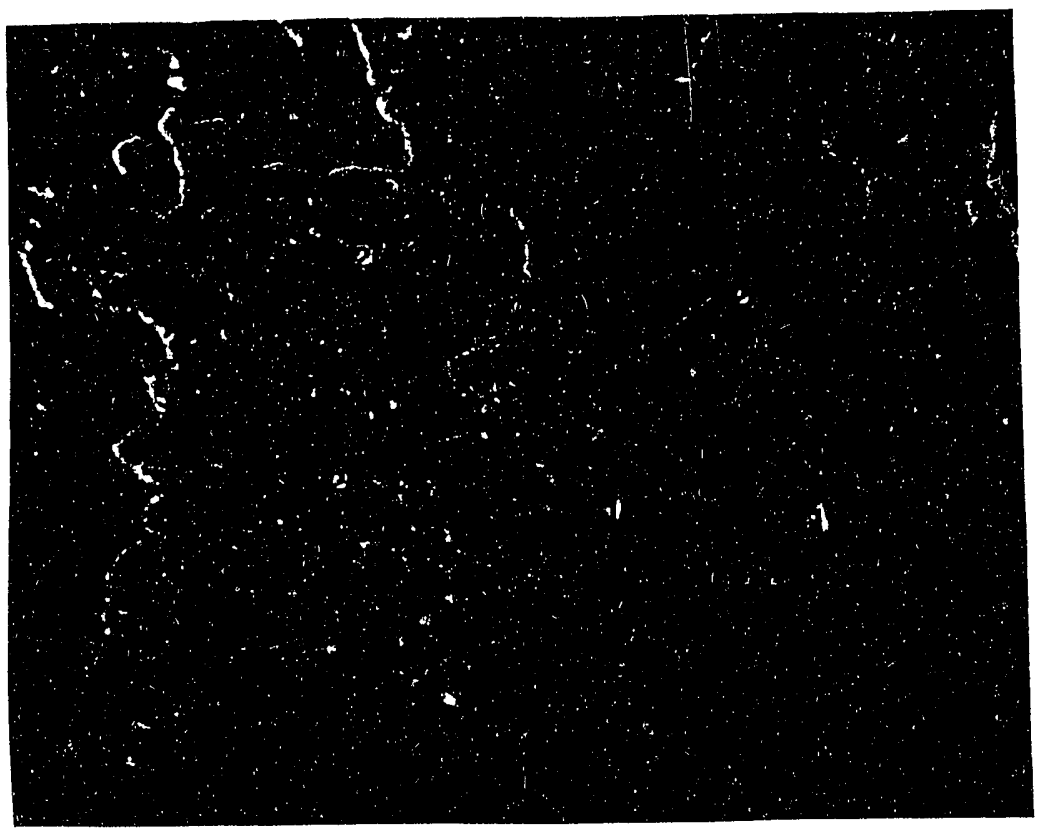

FIGURE 5. Optical micrograph of the $\mathrm{M} 2-30^{\circ} \mathrm{C} / \mathrm{min}$. sample (1: uranium containing phase, 2: (U,Zr)C solid solution.)

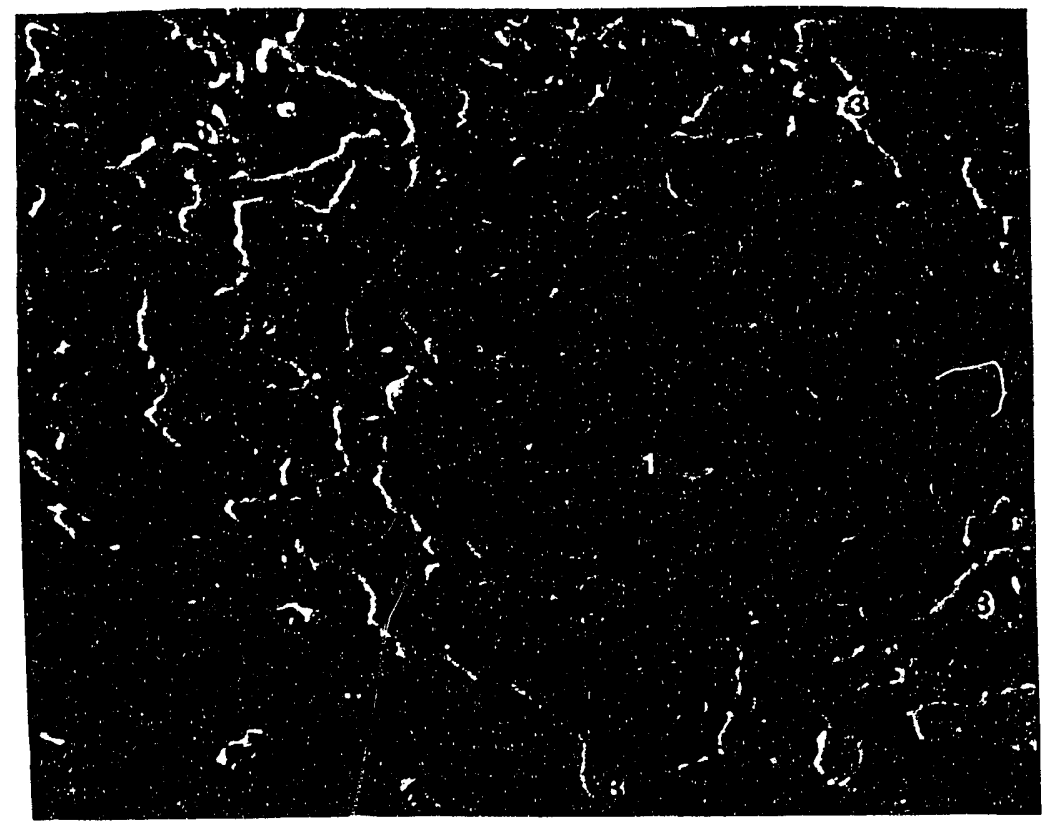

FIGURE 6. Optical micrograph of the $M 5-30{ }^{\circ} \mathrm{C} / \mathrm{min}$. sample (1: ZrC, 2: variable comprosition (U,Z, C) solid solution, 3: UC) 


\section{DISCUSSION}

From the results obtained in this preliminary study, the onset of the combustion reaction was found to depend on the lowest melting point of the reactants and the relative amount of this low melting point reactant. When uranium, which has the lowest melting point among the reactants used, is rresent in a substantial amount, the initiation of the exotherm was observed near the melting point of the uranium as in the case of the $\mathrm{M} 2 \mathrm{sample}$ heatcd at $100^{\circ} \mathrm{C} / \mathrm{min}$. When uranium was absent, as in the case of the M4 samples, the onset shifts toward the melting point of zirconium which is higher than that of uranium. That the presence of liquid facilitates the exothermic reaction can be explained by the higher diffusion and dissolution ratcs in liquid state. This results in more reactant atoms available for reaction at a given time. The higher reaction rate subsequently releases more energy which raises the temperature of the reaction system and further increases the reaction rate. Under this condition the entire reaction process of the sample can be completed in a very short time. If no heat is lost to the environment, the temperature of sample can rise to its adiabatic combustion temperature. This rapid rise in temperature is especially evident in the highly exothermic $\mathrm{M4}$ samples (the $\mathrm{Zr}+\mathrm{C}$ mixture).

The external heating rate has a significant effect on how the exothermic reaction proceeds in an all-solid reactant system. As a sample of this type of system is being heated up to temperatures below the first liquid formation temperature, solid diffusional reactions occur at the contact regions between the reactant particles. These diffusional reactions can form intermediate product phases at these contact regions. At a low external heating rate, the sample spends more time at temperatures for solid diffusion to occur, and substantial amounts of intermediate product phases can form. The formation of intermediate phases have been observed in other exothermic solid reactant systems [Wang et al 1990]. The formation of intermediate products not only reduces the available thermodynamic driving force for subsequent combustion reaction triggered by the presence of liquid [Wang et al.. 1990], but can also form diffusional barriers between reactant atoms. Higher heating rate reduces the amount of intermediate solid product phases formed from: solid-diffusional reactions. This results in greater amounts of initial reactants available for the accelerated exothermic reaction when the first liquid formation temperature is reached. This effect manifested by an exothermic peak was seen in the case of the $\mathrm{M} 2$ sample heated at $100^{\circ} \mathrm{C} / \mathrm{min}$. but not in the 30 ${ }^{\circ} \mathrm{C} / \mathrm{min}$ case. In both cases, the reacted samples formed practically the same amount of the expected product, see Figure 3. This fact indicates that the reaction of the $30^{\circ} \mathrm{C} / \mathrm{min}$. sample occurred at a lower rate but completed over a longer period of time, while the reaction of the $100^{\circ} \mathrm{C} / \mathrm{min}$. sample occurred at a higher rate but completed over a shorter period of time. In this study, many of the other samples heated at $30^{\circ} \mathrm{C} / \mathrm{min}$. also did not show detectable exothermic effect; this however does not indicate absence of exothermic reactions during the heat up process. In all cases, the results of $x$-ray phase analysis show that reactions to form solid solution and/or carbides have occurred.

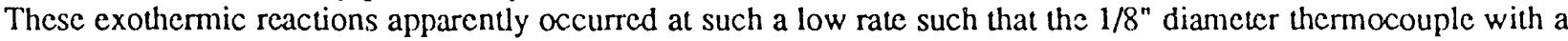
relatively large thermal mass is not sensitive enough to detect the temperature change.

The solid solutions are more easily formed from compositions containing elemental $\mathrm{U}, \mathrm{Zr}$, and $\mathrm{C}$ powders. While $\mathrm{UC}_{2}$ is a more readily obtainable reactant but is a less desirable starting reactant because of its higher melting point $\left(2450-2480^{\circ} \mathrm{C}\right)$ and the lower thermal effects of samples, Figure 1. As shown in both the M3 and M1 samples which started with uranium contained in $\mathrm{UC}_{2}$, the reaction actually resulted in two partial solid solution phases, Figure 3 and Table 3, rather than a single solid solution expected.

Finally, the effect of inadequate mixing is demonstrated in the M5 sample which was prepared by hand blending appropriate amounts of M2 and M4. Although this sample is expected to sore easily form a single solid solution than M2 due to a higher enthalpy of reaction, the reacted product showed incomplete reaction and contains mostly $\mathrm{ZrC}$ and minor amounts of $\mathrm{UC}$ and $(\mathrm{U}, \mathrm{Zr}) \mathrm{C}$ solid solutions. The microstructure also exhibited a rather heterogeneous distribution of these phases. This leads to the conclusion that mixing is an important factor in preparing powder reactants for this reaction process.

\section{CONCLUSION}

This preliminary study has demonstrated the feasibility of synthesizing (U,Zr)C solid solutions starting with $U$, $\mathrm{UC}_{2}, \mathrm{Zr}$ and $\mathrm{C}$ reactant powders under combustion conditions. The $\mathrm{UC}_{2}$ has a higher melting point and contributes less reaction enthalpy, and so is less capable of achieving complete reaction in the bulk sample. Our results also show that the initial composition and the heating rate have a significant effect on the nature of the reaction process. As expected the degree of powder mixing also affects the completeness of the reaction in the bulk sample. 


\section{Acknowledgment}

This work was supported by the Department of Energy. The authors gratefully acknowledge Jose Archuleta for we $x$-ray diffraction work, Richard Mason and Leonard Trujillo for the thorough SEM work which helped identify the spatial distribution of the phases in the samples, and Walter Stark, Jr. for reviewing the draft.

\section{Reference}

Butt, D. P. and T. C. Wallace (1993) "The U-Zr-C Ternary Phase Diagram Above 2473 K," J. Am. Ceram. Soc., 76(6): 1409-19.

Holley, C. E., Jr., M. H. Rand, and E. K. Storms (1984) "The Chemical Thermodynamics of Actinide Elements and Compounds : Part 6, The Actinide Carbides," International Atomic Energy Agency.

Kubaschewski, O., C. B. Alcock, and P. J Spencer (1993) Materials Thermochemistry, 6th Ed, Pergamon Press, NY.

Munir, Z. A. (1988) "The Synthesis of High Temperature Materials by Self-propagating Combustion Methods," Ceram. Soc. Bull., 67:342-49.

Munir, Z. A. and Umberto Anselmi-Tamburini (1989) "Self-propagating Exothermic Reactions: The Synthesis of High-temperature Materials by Combustion," Mater. Sci. Repts. 3:277-365.

Storms, E. K. (1957) Refractory Carbides, Academic Press, NY.

Subrahamany, J. and M. Vijayakumar (1992) "Revicw: Self-propagating High-temperature Synthesis 1992," $J$. Mater. Sci. 27(23): 6247-273.

Wang, L. L., Z. A. Munir, and J. B. Birch Holt (1990) "The Combustion Synthesis of Copper Aluminides," Metall. Trans. $B, 21 B(6)$ : 567-77. 

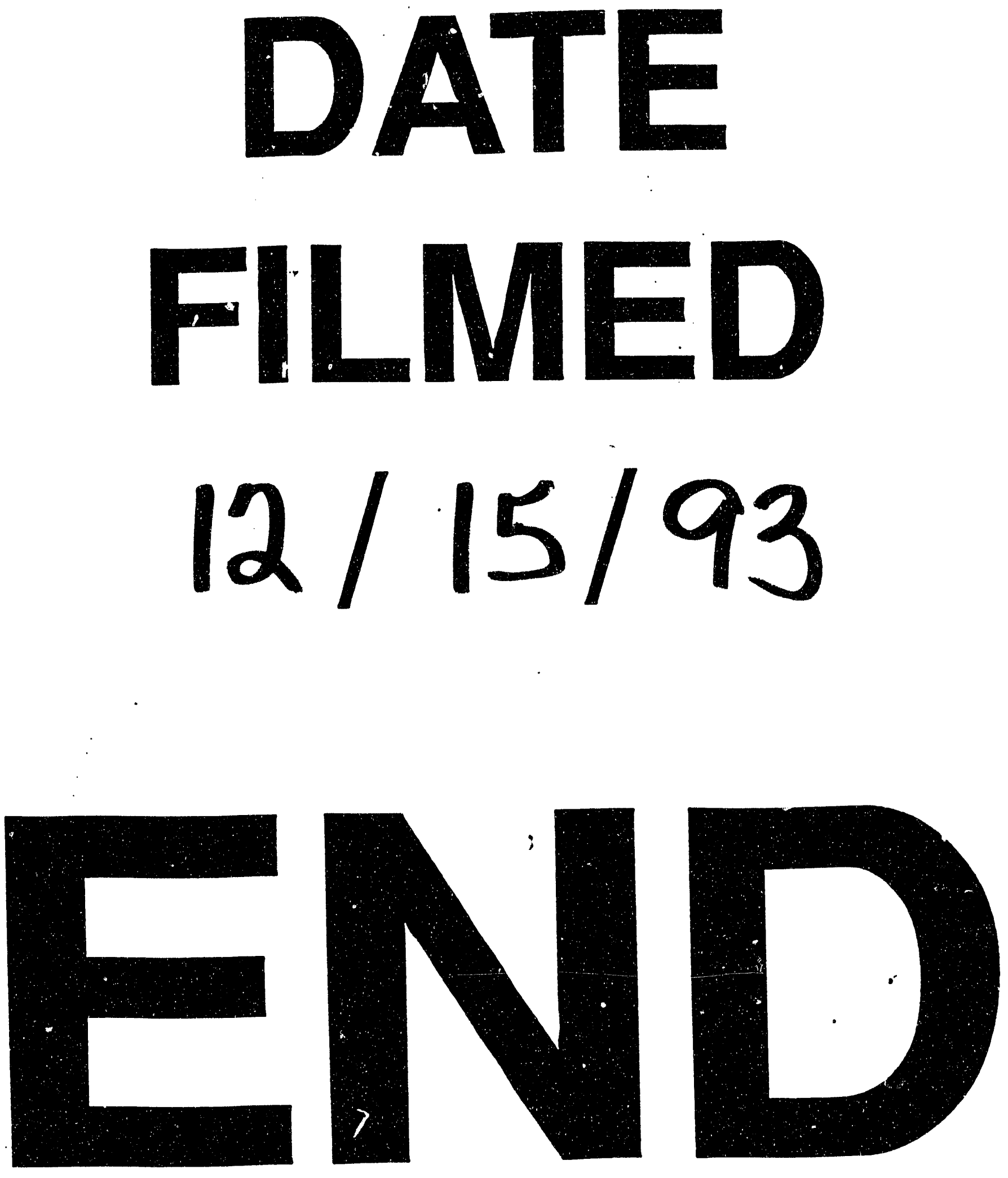